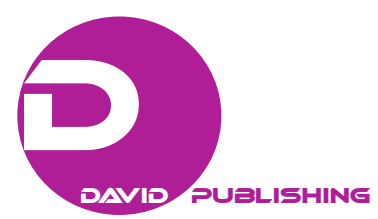

\title{
A Sri Lankan Development Communication Model: Use of Traditional Forms of Communication*
}

\author{
Manoj Jinadasa, Chandrasiri Rajapaksha \\ University of Kelaniya, Kelaniya, Sri Lanka \\ Upali Pannilage \\ University of Ruhuna, Matara, Sri Lanka
}

\begin{abstract}
This paper explores the potentials of traditional forms of communication in rural development communication. Experimenting a local development communication model that can be used at the grass-root level communication at the community development programs in Sri Lanka is the research objective. This study is a participatory research. Live participatory observation, impact analysis using a questionnaire and direct interview tools were used to analyze the impact of the creative model. This research study was experimented at Rasnayakapura divisional secretariat, Sri Lanka from 2004 to 2005 . Results suggest that the traditional forms of communication can be utilized as a useful instrument in the rural community programs more than the dominant use of mass media and conventional use of small group communication. Forms of traditional communication are rich in communication because of their closeness to rural life, credibility, Utilization of familiar signs \& symbols, Participation of the same community, collective presentation, Utilization of past experiences, plot and the stories from their own life and psychological understanding (attraction, attention, rationality). Communicating a message through entertainment was the practice of this model. Finally impact analysis confirmed the success of the model.
\end{abstract}

Keywords: traditional forms of communication, community empowerment, development communication, Sri Lankan Folk-Lore

\section{Introduction}

Contemporary development discourse has gained much regard among the academics and development practitioners. Interpretation of development cannot be limited into a single approach. This has been taken into a multidisciplinary approach. Defining development includes variety of perspectives and dilemmas. However, the most updated theoretical explanations for development after 1960s questions the suitability of the western perspective of development, so that the applicable methods for their regional development are determined by the regional cultural and social evolutions and developments (Pieterse, 2001; Hartwick, 2005; Jinadasa, 2011c, 2014).

\footnotetext{
* Acknowledges: No potential conflict of interest was reported by the authors.

Manoj Jinadasa, MSSc, Senior Lecturer in Mass Communication, Department of Mass Communication, Faculty of Social Sciences, University of Kelaniya.

Chandrasiri Rajapaksha, Ph.D., Senior Professor in Mass Communication, Department of Mass Communication, Faculty of Social Sciences, University of Kelaniya.

Upali Pannilage, Mphil, Senior Lecturer in Sociology, Department of Sociology, Faculty of Humanities and Social Sciences, University of Ruhuna.
} 
In the first stage, development was defined as the growth of both quantitative and qualitative aspects of social needs and services. But later, it has been changed into a different analysis by the conceptual and theoretical constructions based on the respective socio cultural and political movements in the world (Jinadasa, 2014, 2015). To measure physical and capital development, a tool such as GNP (gross national product) has been used for decades. But in the later phase, measuring development by using this type of tools has not been successful. Micro level social issues and development problems should have been relatively more attuned in these measures. Sustainable development is a contemporary fruit of this discourse. Sustainable development is the development that meets the needs of the present society with compromising the ability to receive the needs of the future generation.

This study is limited to the rural community development sector in Sri Lanka. Rural development has been a familiar component in developing regions. In particular, south India, Africa, and Sri Lanka, which are some of the major regions of implementing rural community development as a basic development practice. The World Bank has suggested a more comprehensive concept and method of rural development. Rural development has been defined as a strategy to improve the economic and social life of a specific group of people, that in the rural poor including small and marginal farmers, tenants and the landless. The report of the World Bank explains, a rational program of rural development should include a mixture of activities including projects to raise agricultural output, create new employments, improve health and education, expand communication, and improve housing. The nature and content of any development program or project will reflect the circumstances of the particular country or the region... (The world bank report, 1975, pp. 28-40).

Development communication refers to a spectrum of communication processes, strategies and principles within the field of international development aimed at improving the conditions and quality of life of the people struggling with underdevelopment and marginalization. Reflective of the field's historical evolution, development communication is characterized by conceptual flexibility and diversity in the application of communication, techniques used to address the problems of development. Some approaches in the tool kit of the field include: information dissemination and education, behavior change, social marketing, social mobilization, media advocacy, communication for social change and participatory communication, communication for informed decision. Development communication is for the betterment of the society though raised from a particular group but affect the whole mass for the better.

The term "Development communication" was coined by Nora C. Quebral a professor at the University of Philippines Los Banos. Development communication in practice is a relatively new phenomenon. One may argue that it existed right from the beginning of human history, just didn't have a name such as this. The truth is it has never existed before 1970's as a discourse. It has also suffered a lot in the hands of people and institutions who have mistakenly thought development communication is promotion of development, a different kind of public relations best achieved through a host of products like videos, newsletters, case studies and so on. In reality, it is inspirable from any real development effort. it is a part and parcel of any development agenda (http://enwikipedia.org/wiki/developmen communication).

In this field Wilbur Schramm, Daniel Lerner and Everett M. Rogers played a prominent role to establish as a separate communication discipline which relates to development discourse. In 1964, Wilbur Schramme in his research carried out by using African and Latin American tribsman titled Mass Media and National Development emphasis on the importance of media in terms of motivating and integrating the nationality 
and development. In 1958, Daniel Lerner made a research from Middle East regions titled Passing the Traditional Society: Modernising the Middle East, emphasis the media can be a tool for development by working as a mobile personality and empathy for the development community and he reads the importance of urbanization and how it relates to development along with growing mass media in the middle-east countries. In 1962, Everett M. Rogers in his book Diffusion of Innovation concerns how information dissemination can enhance the innovation in a developing society. For this purpose he urges, that Mass Media and other forms of communication can be a tremendous support. However, these western experiments were highly criticized for their partiality towards the modernization model. These theorists were also blamed for their hidden work for the American cold war practices after 1950 with the new manipulation with the project of eradication third world poverty. As a result of this some keen theorist and practitioners were emerged from the developing areas by their use of local cultural and traditional forms of education for the community communication projects.

Use of traditional communication in India in the rural community development in participatory development program has many potentials (Nair \& White, 1993; Belbase, 1991). In Latin and Brazilian context there are many affectivities in using culture and participatory forms of commination in empowering people for the development (Bordenave, 1976; Freire, 1968). In considering the importance of national economy in Japan, local cultural communication remains much communicational applications (Oshima, 1982). In Zimbabwe, traditional thought and participatory communication make an effective communication in the development practices (Ascroft, 1971). In Philippines, use of participatory communication has made some productive communication in the local cultural communication (Quebral, 1971). This theory was much elaborated by her students in local and international level (Felix Librero, Pedro Bueno, Antonio Moran, Alexander Flor, Rex Navaro and Maria Celeste Cadiz).

In Sri Lanka, culture, Buddhist religion, traditions, histories and folk-lore have many different aspects to attract community in the new development campaigns than mainstream mass media (Dissanayaka, 1984, 2008, 2009, 2014; Jayaweera, 1993; Jayaweera \& Amunugama, 1987; Gunasekara, 1985, 1990; Gunarathna, 1991, 2007; Bond, 2004; Macy, 1985; Jinadasa, 2011, 2014, 2015). Further, some social projects; Sarvodaya Shramadana Movement (Ariyarathna, 1986) Sanasa Movement-Sanasa Grammeya Bank (Kiriwandeniya, 1978) have been much developed in the local development scenario by the use of traditional forms of communication associated with the culture, Buddhist religion and folk-lore. Moreover, street drama which has been much popular among bottom level communication in the local developmental campaign, has largely been developed by Gamini Haththetuwagama and Shesha Palihakkara, then it was widespread by later novel creators. However, use of Tamil street drama; Therukkuthtu, Nattakkuthtu, Kamakkuthtu have provided the foundational platform to originate such kind of traditional communication in the grass root level, while it has made a significant contribution to Indian Communities in the respective places of living in both Thamil Nadu (India) and Sri Lanka. Thus, Participatory communicational forms can be productively applied for the rural development communication while traditional forms of communication have been sourcing for making effective communication.

Traditional media are the indigenous channels of communication. They are not simply old-fashioned forms of entertainment. As media they are alive. Traditional forms of communication express the folk mass consciousness, which is being embedded in the folk society. Communication researches have immensely exploded the existing characteristics of folk media, which can be effectively used for rural development 
communication programs. As media they are alive and receptive to new ideas. They are nurtured through oral and functional sources. In brief, traditional media provides channels for expressing socio-ritual, moral and emotional needs of the language groups to which they belong.

So long as the contents of traditional media provide entertainment and fulfill communication needs of the groups. They will retain their worthiness as expressive agents. The more the traditional media prove their acceptability to new ideas, the more they will be regarded useful as media of communication. In this process, the contents may change, but without disturbing their structural characteristics. This is what makes them relevant to the society.

In this sense, traditional forms of communication have been used for the development communication programs all over the world. It is a trend of development communication. It has achieved a rather pleasurable productivity mode than using the mainstream mass media. In order to disseminate development messages in countries like South Africa, South India, and Latin America, several experiments and practices have been made in the rural and traditional places of developing programs. In particular, this type of traditional Forms of Communication has widely been applied to communicate messages like STD, Disaster, Sexuality, Family Planning, Nutrition, Social Harmony, empowerment in the development projects.

In this, the authors explored Sri Lankan traditional forms of communication: Sri Lankan traditional dance, drama, ritual, mask dance, drumming, singing... to make a local development communication model that can be applied in the rural community development with much confidence.

\section{Materials and Methods}

\section{Research Objective}

To explore the capacities of traditional forms of communication to create a development communication model from folk media performance, that can be used at the grass-root level communication for rural community development programs in Sri Lanka.

\section{Other Objectives}

- To explore the strengths and effective communication of traditional forms of communication in terms of development communication practice.

- To experiment for an alternative communication usage in the capacity of rural development communication.

\section{Research Problem}

Can Sri Lankan Folk Forms of Communication be used for development communication? If So, How is it applied in development communication practices in Sri Lanka?

\section{Problem Statement}

In the sphere of development communication, traditional forms of communication have been utilized effectively for many parts of the world. Folk media has been used creatively to disseminate development messages to target groups in the rural development programs of the countries such as India, South Africa, Latin America, and Japan. Nowadays in Sri Lanka the same trend can be seen at some of the major development programs like Gamideriya, Sarvodaya, Sanasa and other regional and rural community development programs of non-governmental organizations. In this case, Street drama has been the major tool of folk media in many development communication programs. Moreover, a variety of traditional forms of communication, which are 
familiar in Sri Lanka are capable of this practice. They have a potentiality to be used in much creatively and innovatively for the pertinent development communication packages than usage of mass media for the said purpose.

\section{Research Methodology}

As this study was conducted using mixed approach both quantitative and qualitative methods were used, so that participatory research design was applied.

\section{Participatory Research}

Participatory research method was used because of this research based on the practical research experiment. It was carried out at the Rasnayakapura divisional secretariat in Sri Lanka, covering the 27 villages. The experiment was conducted from 1st of August, 2004 to 31st July, 2005 for one year period. This communicational model has been used to promote social mobilization, social communication and community empowerment by using their own traditional folk-media. This program was another part of the main program of the community governance development project at Rasnayakapura divisional secretariat conducted by the Intermediate Technology Development Group (I.T.D.G-South Asia).

Two major tools used to evaluate the impact of the proposed communication at the community.

\section{Live Participatory Observation}

When the cultural play is showing at the same time. We can analyze the following aspects as the dialogue between actors and the community, dialogue between the communities, verbal and expressions, gestures and postures, participation, interactive-communication, responses, reactions and feedbacks.

\section{Impact Analysis}

Impact analysis was used after the cultural show within a month or two months. This consist of the following tools as:

- The questionnaires to be presented to the field members;

- The directed Interview, assess the community participation;

- Acquiring new knowledge;

- Acquired new behaviors;

- New participation for the development programs such as community involvements.

\section{Data Collection}

First of all, it was studied the pertinent development program in which an effective mode of communication is needed. The main goal was to the project, had been empowering community participation for development. After that, it disclosed the rural area in which that development project has to be implemented. Then it prepared the performance based communication model. The youth and teenagers were trained in it and within the three months period they were able to narrate the overall cultural performance in front of the villagers in the evening sessions at familiar places such as Kamatha (open threshold at the paddy field), Praja Shalawa (hall of the Local body in rural village), Weu Ismatta (upper ground of the water tank in rural agricultural village).

\section{Data Analysis}

It was tested the differences between pre and post participation related to the cultural performance. How the cultural show impact towards enhancing community participation to the places in which their decision can 
be taken into development planning and implementation. For this purpose, it was used live participatory observation at the same time in which the cultural show is being performed. And impact analysis was conducted to test the behavior change after the new communication application.

\section{Limitations of the Study}

As in the participatory observation, responses of the community could be subjective based on their livelihood and environmental effects. Further, as other development program have used small group communication and public speaking, when this cultural performance was held, it was much appreciated by the rural communities as different form of community meeting.

\section{Sri Lankan Development Communication Model: Use of Traditional Forms of Communication}

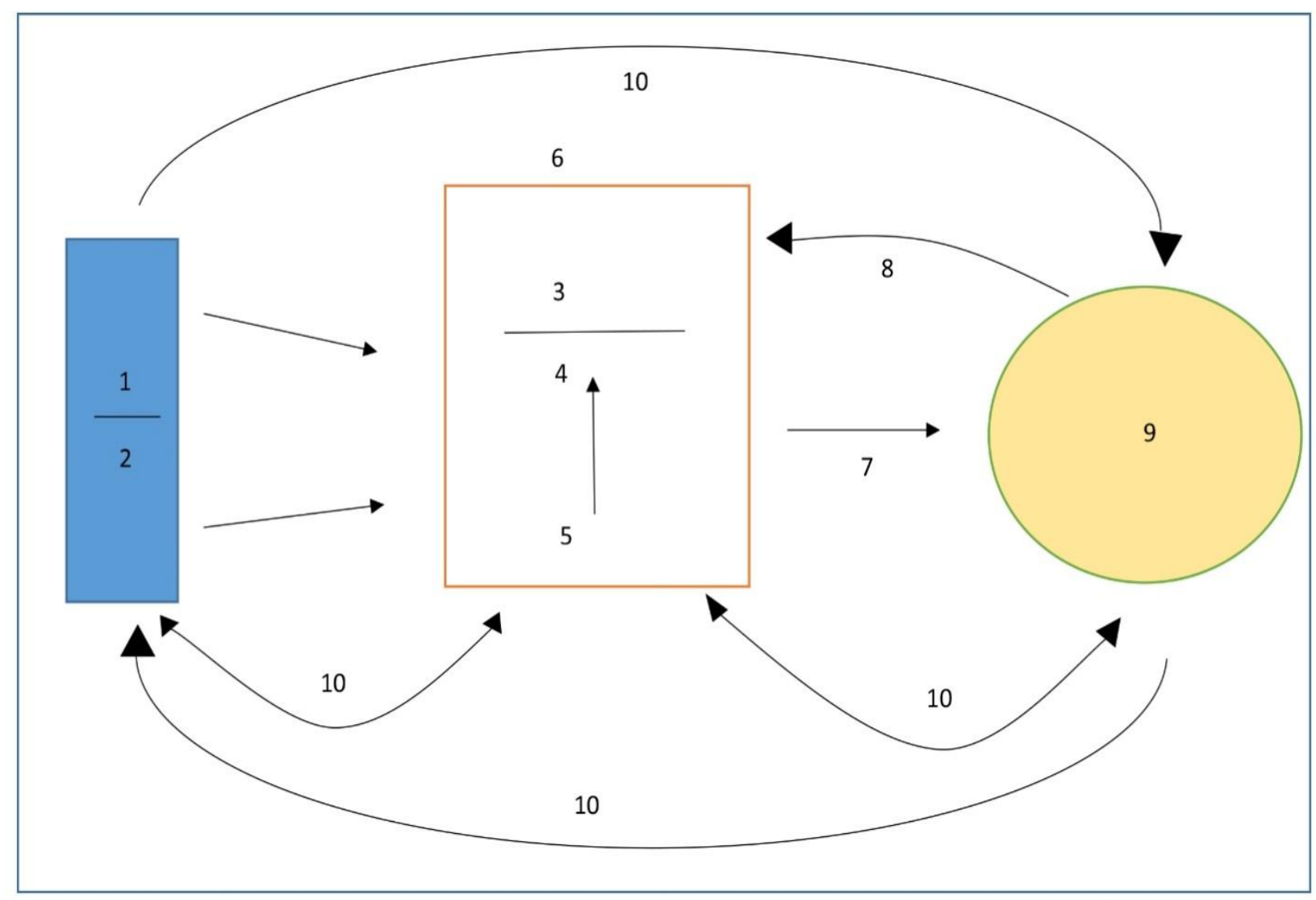

Figure 1. Illustration of proposed model of rural development communication.

In the constructing of this communication model, there are key serial steps:

(1) Understanding of development project and its communication objectives (Communication Necessity)

(2) Understanding of the rural village, communication systems, rural development necessities and development communication issues(Place of the Audience)

(3) Development communication script writing (Message Formation)

(4) Forming a cultural troop from the rural community (specially from the youth and teenagers) (Channel Formation) 
(5) Training effective communication and performance skills for the cultural troop (Empowering the Channel)

(6) Producing development communication script (Editing the Message)

(7) Implementing communication production at the rural community level (Sending)

(8) Measuring feedback of the development communication performance (Feedback)

(9) Developing communication model in terms of the community interaction and feedback (Effective Communication)

(10) Impact analysis (Process).

\section{Understanding of Development Project and Its Communication Objectives}

\section{Situation Analysis}

In the face of situation analysis of communication planning for solving identified development problems, we recognized some of the situations that prevails in the place of development. The Rural Community Good Governance program has been implemented by the ITDG in this region in order to eradicate the prevailing development problems. The main objective of this project is to enhance the life condition and promote the quality of governance in the rural political system, in the occasion of taking decision, proposing and implementing this in their own place.

In search for identifying development problems in the rural area, we found following items:

(1) Rural disharmony in the space of taking political decision

(2) Lack of empowerment over the youth community organization

(3) Absence of allocating funding for rural development due to party politics

(4) Traditional leadership discourage the youth leadership

(5) Bordering the rural sector with urban development facilities

(6) Lack of government intervention for economic development programs in the rural area

(7) Lack of establishment of the industries over the rural area

(8) Lack of transport facilities

(9) Undeveloped rural roads

(10) Undeveloped water irrigation system

(11) Absence of using proper technology

(12) Inability of implementing appropriate technology to develop rural basic needs like roads and irrigation system etc.

(13) Traditional barriers for rural organization such as caste, race, ethnicities etc.

(14) Biasness for various NGOs for taking financial grants.

Now, To expel these rural development problems, ITDG introduced a particular development project called the Rural Community Development Program. This project was implemented for five years from 2001 to 2006 December at the Rasnayakapura Divisional Secretariat, covering 27 villages with Other two villages called Unale and Kudamithawa which are situated near the Rasnayakapura Divisional Secretariat.

With this development project it was urged to have a particular mode of communication to disseminate the project objectives and fundamental massages to the target audience known as rural villages.

It was understood that the communication system for rural development communication, should be essentially experimental and customer oriented communication. Therefore first of all we had to explore following aspects: 
- the objective of development program

- its stakeholders

- participants

In addition to that, we were eager to know the existing rural village communication systems of the village

- traditional communication methods

- mass media usage and its impact towards rural life

- education, health, transport and information level of the village.

After this stage we were going to plan the appropriate communication system for disseminating development massages for the rural development area.

\section{Institutional Framework}

For this work some of the other institutions were also incorporated. In that case Sangrama, a regional Non-Governmental Development Organization, situated at the Nikaweratiya Town was the main activator. Rasnayakapura Divisional Secretariat office and Nikaweratiya Pradeshiya Sabhawa (Local Council of governance) were the other two regional institutions, which incorporated to this program.

ITDG provided funding and technical consultation that helps to convert the proposed plan into action. Organizational hierarchy of ITDG of this program is mentioned below:

(1) Country Director

(2) Program Manager

(3) Project Manager

(4) Consultant of program

(5) Sangrama Director

(6) Field officers.

There are some community level officers who are for grass root level operation of the project:

(1) Grama Seva Niladhari (Village Governor officer)

(2) Krushi Paryeshana Niladari (Agricultural Research Officer)

(3) Pradeeshiya Shabha Manthri (Member of the Regional Council).

They are titled as Government officers also participated in this program.

A particular Community Organization called Praja Sabha (Community Council) was established with the cooperation of villagers to implement the program effectively in the village. Each village had a Praja Sabha in all 24 Villages.

The main objective of the program is to enhance the power and to strength the participation in terms of rural development needs. Ultimately the villagers can have much capacity to take decisions and to make influence on the government sector towards their rural development needs. This process achieved the empowerment of the rural citizens. The fundamental issue of rural development as I.T.D.G understood from the sphere of situation analysis was lack of pertinent power and understanding in order to participate in the development process with their-own aspiration and impression.

Goals of the rural community governance development program:

(1) To establish an environment which fulfilled the wants and needs of the rural community in their development programs;

(2) To identify the objectives of the Rural Community Governance development program; 
(3) To develop and implement a community development model for rural development;

(4) To implement a community participatory rural integrated development plan for Rasnayakapura Divisional Secretariat;

(5) To strengthen the rural level community organization for implementing community participatory rural integrated development plan;

(6) To establish a forum to gather community participation in regional level for rural development;

(7) To introduce a developed community governance model for other development programs in the country.

When it is going to understand the prevailing development problems, we found them in terms of following serial order with special reference to Rasnayakapura Divisional Secretariat (See Appendix B).

These development issues are categorized into several fields for the sake of proper planning for addressing them in the stage of implementation the relevant development program.

Target development field consisted of 27 Grama Niladari Divisions. Experimental communication model was performed at $27 \mathrm{GN}$ divisions (See Appendix A).

A particular Community Based Organization called Praja Sabha was established in every GN Division in order to implement the development programs in the rural level. Evaluation and monitoring mechanism was carried out in every month at the Sangrama office, which is the place of implementing rural programs consultation with the I.T.D.G.

Proposed Experimental model of development communication was conducted with the full cooperation of the members (Rural Villages) of this Praja Sabha in every instance.

\section{Understanding of the Rural Village, Communication Systems, Rural Development Necessities and Development Communication Issues (Place of the Audience) (Communication Pre-research)}

It was needed to make a communication system to disseminate the relevant message for the rural grass root level of the Rural Community Governance development program. Basic objective of preparing a particular model of communication was the use of effective communication of the rural community governance. It found several objectives in terms of making this kind of communication model as a part of the development project.

They are as follows:

(1) To communicate the message of rural community governance;

(2) To empower the rural community via the grass-root level communication mechanism;

(3) To strengthen the ability to participate for the development program;

(4) To increase the rural community for the community based organization called Praja Sabha;

(5) To increase the youth community for the rural community governance program;

(6) To dispel the misconception of the development program;

(7) To develop the communication and performance skills of the rural youth;

(8) To create a platform for presenting development skills of the rural community;

(9) To create a platform for intervention for the on-going development program;

(10) To understand the traditional communication forms of the rural community.

First of all it was interesting to study the geographical field of the development in order to understand the 
place of the audience. Therefore, it was very necessary to live with the rural community at least for one month. The duration of this period depends on the development project and its communication objectives. The communication researcher should live with the target development area in order to understand the socio-cultural situation of the rural community. In this, it was concentrated on the following issues:

(1) Organization and hierarchy of the rural community;

(2) Current development problems of the rural village;

(3) Social stratification and social system of the rural village;

(4) The prevalent understanding of the development project;

(5) Misconceptions of the development program and the funding organization (I.T.D.G);

(6) Traditional communication patterns of the rural community;

(7) Mass media and communication usage and audience of the rural community;

(8) Language and rural language dialects.

Organization and hierarchy of the rural community differs from $G N$ division to $G N$ division. This has to be understood in detail. How has the traditional leadership influenced intaking decisions? How does agricultural system and village life administer over the traditional rural governance? What are the roles and responsibilities of the rural community?... are some of the information that should be collected in this search. Understanding of above facts necessarily helps to plan a proper communication system for the program of proposed development communication.

Understanding of the existing rural development problems is very important. When it is going to plan a communication model, the content of the message is based on the rural development issues and problems. These issues should be addressed from the proposed communication model. This knowledge helps to decide the structure of the development communication model. Rural development problems reveal the prevalent socio-economic situation of the rural community.

Rural communities are consist of different castes, races, religions... and so forth. These differences and social stratifications provide a foundation to define the appropriate communication pattern. There are certain intrinsic rural problems which are related to the caste, race religion and community participation in development.

In the meantime, it is very important to measure the community awareness of the on-going development program in the rural area. Sometimes, different levels of understanding and misconceptions can cause to immerge issues as well. In this experiment. There were several social problems, which were arising due to the ignorance of the development project and getting more and more misconceptions of the project. Some understood this as a mechanism of disseminating the Christian religion like other certain NGOs, which work in the rural places at that same time. On the other hand, these things should be well communicated with expressing reality and it should be considered to make real awareness towards the rural community. For an example, in this communication campaigns it focused to dispel the religious misconceptions and make a thorough awareness of the rural community governance program and the importance of being governed by the rural community themselves.

When it is preparing a grass-root level communication model it is very important to consider the traditional forms of communication, which can be collected from the rural area in which we apply for intended development program. The proposed model of development communication can be made out of the traditional forms of communication, which can be found from the same rural area. In this venture; it is worthwhile to have 
a general knowledge on the mass media, communication audience and usage of the rural community as a part of communication planning. To make varieties of communication messages it is essential to know about the language prevalent in the area and other dialects if any.

\section{Development Communication Script Writing}

It is very necessary to prepare a script for communication performance before one move on to producing a development communication performance. Script should include the structure and content of communication that is going to be performed. Always it is very productive to use a script for the designed communication mode before it is practiced in the ground level. In this, designed mode of development communication script is written in terms of the prevailing development issues and communication necessities. Script should cater the available communication avenues. Script should be included the following items. Each item embedded in a particular communication message that has to be addressed to solve the existing development problems in the rural village. Script has a serial order to be performed in the communication:

(1) Announcement for the evening Cultural Show (Development communication).

The news of this event is carried out in the village through a Daul drummer. It is called Anaberaya in the traditional Sinhalese vernacular. Anaberaya was used in ancient kingdom era, as a means of communicating message from the king to the people at the grass-root level. Anaberaya can be creatively used to announce the evening performance better than loudspeakers or any other high cost equipment in the modern sense.

(2) Time of performance:

Evening time $7.00 \mathrm{pm}$ to $9.00 \mathrm{pm}$.

(3) Place of performance:

A popular place to which rural community gather without any obstacle. For an example: Threshing hold, a ground floor (in the paddy field) close to Praja Sabha, a place easy to gather for the rural community.

(4) Commencement:

Actors and actresses are coming with touch lighted known as Huluatta (in the Sinhalese traditional vernacular) to the stage of playing from different places without any pre-communication, surprising to the gathering audience. They all denote rural villagers. After their coming, two special persons represent traditional ritual characters similar to master (Gurunnanse) and the henchman (Paraya). They are instantly coming to the stage and announce the next item in a satirical manner of acting which provokes the audience to laugh.

(5) Serial Order of the Items

a. Thematic Song

A theme song should be created using the main objective of the development project and the main objectives of communicating the significance of development project, So that finally seek to increase the credibility and reciprocal understanding between project and people. This song is a group song. It is very captivating to use certain forms of local dancing and a relevant dramatic performance to send the message effectively. It denotes the starting point of the entire communication performance. The commencement should be much powerful with following communication objectives:

- introducing the significance of rural community governance;

- main objective of development program;

- emphasis of main communication issue that is to be designed for communication from this mode. 
b. Song that depicts community harmony

As the second item, this song is created to acknowledge the importance of the harmony of rural community for the development progress. It is sung as a group performance with certain chorography of dancing, dramatic gestures and musical performances.

- concentrating on the importance of rural community harmony for their-own development;

- productivity of the community participation for the development process.

c. Satiric Dramatic dialogue

A dramatic event that narrates a comedy dialogue is the third item of the program. This expresses existing rural problems of government service. It sarcastically criticizes the pollution and imbalance of government servant who work in village. Problems like misconduct of the government service, pollution, political biasness, private beneficiaries, briberies are dramatically narrated with comedy. At last the event concludes with message about the importance of community empowerment in controlling such a situation.

d. Short drama event that addresses a particular rural problem

Several performers participate to this short drama. It is subjected to a certain rural problem of either community or the rural governors. Especially in this program there was minimum community participation for the development program. People understood this as a program for converting their religious ideology into another one as a popular understanding towards the NGOs. It is suggested to dispel this error by using a dramatic event. Using a therapeutic communication, in this short drama discusses several rural community problems and finally come to a definite solution giving them a thorough understanding with real practical examples. It is very effective to use many traditional languages and communication styles to build up a good proximity with the rural community. In this endeavor, popular language dialects, regional cultural customs, beliefs are some of the productive cultural assets that can be utilized to enhance the relevant messages.

e. Stage drama song that communicate a certain development idea

We can use popular stage drama songs to enthuse the rural audience while presenting development thoughts. In this case, we can use songs from stagedramas of popular (like Rathuhattakari, Naribena, Kalagola, In Sinhala dramas). Creating entertainment with classical appreciation is also defined as a goal of development communication towards illiterate rural community. The practice of using popular stagedrama events and songs for such a development communication mechanism take a credibility and closeness in communication with the rural community. Deliberately this build up understanding, interactive knowledge between publics of the intended development program. This practice can be effectively used for rural community.

\section{f. Folk song}

Sri Lankan tradition of Folk Music is full of folk lyrics, rhythms, legends, myths. Folk song can be categorized into many fields such as Pal kavi, Goyam Kavi (poems, which are sung in the field of Paddy), Nelum Kavi (poems in planting paddies), Karaththa Kavi (When Bullock cart are driving), Paru Kavi (when boats are driving), Pathal Kavi (when in the Mine), Bamara Kavi (when go to take bees honey from the forest). Folk song depicts rural thought and their expression in its natural form. All the communication forms of folk songs like language, musical rhythm, structure, story, experience are mush closer to the rural life. Therefore, it has no difference to make confidence to the development message towards the rural community in case of using folk song. 
g. Creative ritualistic dance drama that dispel the myth from the rural community

We are proud of having a big ritual dance and drama in every part of the country. Ritualistic dance has been used to expel the psychiatric illnesses teaching the reality to patient in front of the other all rural community participation. Devil dance of the law country can be attractively used to expel the myths and erroneous misconceptions of the rural community. Creative dialogues of Devi character who wears a special mask and the Master's character (Gurunnanse) can be appropriately adopted in terms of the development project. Drumming, lyrics singing, chanting, worshipping to devils and demons are some of the intrinsic features of the ritual dance and drama. They can be utilized with their structure to address the relevant content to the development project and therapeutically expose to the immerging issues that emerge in the implementation of development project in the rural community. Deconstruct the content in terms of the development program and apply the same structure that has been coming through the traditional performer is the fundamental theory of this performance. Traditional use of exorcism in the devil dance is used creatively as a therapeutic communication to purify the community mind from the existing barriers of the misconception about the development project.

h. Nurthi/ Nadagam Song that depicts community governance

There is a distinguished tradition of musical song in Sri Lanka. It is called Nurti and Nadagama drama song. Nurthi is a type of traditional musical stage drama, which was built in end of 19th century with the association of north Indian (Hindustani) music. Nadagam is also a musical stage drama, which was built in the same era with the association of south Indian music and specially a local drum called Maddalaya was originated as a result of the influence of South Indian (karnatic) music. These drama song are full of expressing the grace, the kingship, comedy, community gathering, heroism, participation etc. These materials have been popular among the rural community for several decades. They have immense caliber in motivating community towards determinism.

\section{i. Kavikolaya (Ballet)}

Kavikolaya has been a creative mode of traditional communication in every rural place in Sri Lanka for many decades. In this communication experiment, this kavikolaya can be innovatively used to communicate a serious message using traditional rhythm and narration style. This is performed by a single person with various performance skills. Kavikolaya event summarizes the overall communication performance at last by pointing the substance of each event with their development value to the rural community.

j. Group traditional drum orchestra that expresses the termination of the program

This is the last event. It uses traditional drumming consisting of Getaberaya (Kandyan regional traditional drum), Yakberaya (low country traditional devil dance drum), Daula (Sabaragamuwa Traditional ritual drum), Thammattama, Rabana, Udakkiya, Bummadiya, Talampota and other related local traditional instruments. Finally this event also expresses the importance of being inharmony when rural people are going to make their homeplaces into a much developed level. And also emphasizing the significance of rural community harmony and participation for their own community governance. Ultimately this whole communication mechanism guides to a most empowered rural community that present their powersin decision making in political, social, economic phases with higher intervention.

In every instance it is expected to have interactions with rural audience when it is performed the cultural events in the creative platform of development communication. It is very necessary for understanding live 
feedback of the rural community in that instance, so that performers can respond to the critical issues of the rural community with the effective communication. Conduction of interactive communication is very essential to continue the communication mechanism with rural participation. Ultimately it foster a mutual understanding with sufficient awareness of the entire development program.

\section{Forming a Cultural Troop From the Rural Community (Specially From the Youth and Teenagers) (Channel Formation)}

After observing the rural community and their communication problems with reference to the activities of the development projects during a period of one month, a notice should be distributed among the rural community by mentioning the future cultural troop. And interested youth and other teens could gather to make a cultural center at the village level with the guidance of development facilitators and authorized development consultants. A special notice of mentioning the above message should be disseminated among the rural community prior to forming the cultural center. In this case, we can use a paper notice that is to be shown in the traditional way. It can be distributed both by hand and notice board in the rural village. This notice should include the criteria of enrolling members for the cultural troop. In this, it is important to request their interest and aesthetic skills.

In the first stage, it is easy to make a single cultural center rather than forming for each $G N$ division. Members can be selected representatively from each $G N$ division and it is possible to prepare a single center. After implementing designed development communication program at some GN division at the basic level, a cultural center for each GN division could be made taking into consideration with the previous learning issues and experiences.

Number of the members of cultural center should not exceed 30 to 40 for keeping the expenses within allocated budget. An interview or formal examination should be conducted to select the members and it should be much fair for every person. There should not be any kind of partial selection, or private interest in selecting members for the cultural troop to avoid discrimination and any prejudices.

\section{Training Effective Communication and Performance Skills for the Cultural Troop}

After being selected the members for the cultural center, a specialized group of cultural performers could be organized to communicate the development messages to the target rural audience. They should be trained on basic elements of effective communication and its practice. They are fully practiced in communication competencies than the theory. In this, it is very necessary to be trained in performance skills. This communication practice rather cater on the live cultural performance skills. It includes:

- music skills;

- dance skills;

- theatre skills;

- presentation skills.

Performance skills can be understood as follows:

- vocal sound practice;

- singing practice;

- music instrumental playing;

- dancing;

- acting; 
- drumming;

- narrating;

- presentation.

These skills could be trained up to appropriate levels in order to perform well in front of a competent rural audience. In particular, every member should be able to perform more than one skill to communicate every message at one time.

The importance of the traditional communication patterns and use of folk language should be highlighted to the trainees. The basic objective of development communication is well taught to them. The fundamental objective of the usage of cultural performances with special reference to the traditional forms of communication is much familiar to the trainees. It is suitable to spend another one month period to initiate the basic skills and competencies of communication and cultural performance.

\section{Producing Development Communication Script}

Next stage comes to produce the development communication script as scheduled in the above chapter. After being trained the skills of communication and performance in the previous stage, trainers are much competent to grasp the relevant cultural items. It could be singing, dancing, acting, playing an instrument, announcing or any other skill related to conduction of the cultural performance.

In this sphere of producing the script, it is better to follow a step by step procedure in order to grasp the cultural item, so that the development messages could be brought up to sufficient creativity.

As a member of the cultural troop each member has to devote his/her contribution in maximum level from playing several cultural items at the same time with immediate change of style. And every performer could be able to perform any item, when it is assigned in an unavoidable circumstances.

It does not need to achieve the completed production of the cultural performance. When it has reached a pertinent level of production within a period of one month the production could be able to implement in the rural audience. This initial implementation gives an astonishing experience to strengthen skills and competencies into higher level. It also provides a platform to avoid existing limitation and constrains in front of interactive feedback of rural community.

\section{Implementing Communication Production at the Rural Community Level}

Finally, the designed communication mechanism should be implemented at the rural community level. In this it has two steps:

(1) Earlier announcement for the evening cultural show using traditional drumming communicator's role called Anaberaya;

(2) Evening cultural show which includes all the forms of development messages (main body of the communication model).

In addition to this, in the early stages. Sometimes it would be necessary to use public notice or leaflet or megaphone announcement in order to popularize the message of the cultural show (communication program) among the rural community. However, later such a usage would not be needed.

Anaberaya can be effectively utilized to disseminate the message of the conduction of evening cultural show in which includes verities of development messages. This is the pre-communication stage. Anaberaya communicator wears a traditional costumes related to the ideal character. He plays a special drum called Daula. By the way he drums it, he announces the special message in the traditional rhythm and style of expression. He 
walks over the village with drumming a special beat that comes three serial beats with similar timing and space. Meantime, after several steps he stops and reads the message loudly. Then the rural villages come to hear this special news.

Organization of the evening cultural show at their rural village is conducted by the strength of Praja Sabha (Community Organization). Members of the Praja Sabha have to make the traditional floor stage in a ritualistic form. It is made as similar as the grounding ritual stage comes in many traditional ritual practices like law country Kolammaduwa or Kandyan Kohombakankariya or Thowilaya.

Food and other arrangements such as communication material, equipments, light, and dressing room for the performers are also prepared by the supportive contribution of Praja Sabha with the support of the rural community.

\section{Measuring Feedback of the Development Communication Performance}

It is very important to measure the feedback of rural community of the designed communication practice. This should be measured under two methods:

(1) Live feedback at the performance of communication;

(2) Social feedback out after performance of communication.

It is worthwhile to understand the live reactions, responses, interactions when the development communication performance is going on. In this performance audience deliberately deliver instant responses to the development messages. It can be a reply to a dialogue of a play of short drama or other action. Live reactions are like follows:

(1) Answer to a question, which is used at the dramatic event;

(2) Sarcastic reply to a critical dialogue of the short play to an actor/actress;

(3) Live singing with the performers;

(4) Autonomous smiling, laughter, somber... on the development message;

(5) Participation for the cultural events;

(6) Entertaining the events;

(7) Rejection of interpretation;

(8) Other physical expressions;

(9) Critical accusation to an actor to his performance.

Other responses can happen among the rural community after the influence of the communication performances. Practical understanding of the development ideas would be immensely distributed later with regard to the interpretations of the rural community. These messages gradually expand over the village with reinterpretation. This is very effective manner at the grass-root level rural communication.

Participatory communication and understanding of such kind of rural development communication is very productive for this model.

\section{Developing Communication Model in Terms of the Community Interaction and Feedback}

When this communication happens at one place feedback, responses or anyother form of suggestions of the audience should be carefully examined. This feedback is a productive source for restructuring the designed communication mechanism. Communication performances need to be edited in terms of the feedback and responses of the rural community audience. This manner of restructuring of the communication model is a must for the sake of developing a productive and effective development communication model. 
In this way, community interaction with the newly designed communication mechanism has been quite important. Every response of the rural community for the communication performance could be evaluated and measured with the intention of developing a most effective communication model. Basically, responses can be categorized into several forms:

(1) Rural language;

(2) Rural customary ways and means;

(3) Ethics and morals of rural communication;

(4) Traditional society;

(5) Misconception;

(6) Reinterpretation.

\section{Impact Analysis}

Final step of the overall development communication model is the impact analysis. The objective of this event is to evaluate the effect and influence of the target communication mechanism. This analysis reveals how proposed development communication has affected to change the traditional society with innovative conceptions and understanding. That would be beneficiary to enhance the rural community participation for the development. Impact can be divided into three levels as:

(1) High impact;

(2) Medium impact;

(3) Low impact;

(4) Neutral impact.

Evaluation of the impact of the designed communication mechanism should be essential to verify the strengths and weaknesses of the proposal model.

Impact analysis can be conducted in two stages:

(1) Periodical impact analysis;

(2) Overall impact analysis.

The effect of the communication is evaluated periodically. This is very important to modify the on-going communication mechanism in terms of contemporary feedbacks. Periodical impact analysis can be conducted once in a month after the performance of cultural show at the rural village.

Overall impact analysis is conducted after the complete usage of cultural show in all the villages. This can be conducted;

(1) Annually;

(2) After the completion of target objectives of the development project;

(3) Before commencing the next development program of the project;

(4) With the initiating of new development project at the same area;

(5) With the implementing of new development program at the different rural area which is close by.

Several tools have been used to collect the data of the impact of development communication of the cultural show. In this impact analysis, there are some steps:

(1) Participatory observation;

(2) Questionnaire;

(3) Interviews. 
Following items can be identified as the indicators of evaluating impact analysis of the development communication model:

(1) Increasing community attendance for the rural community organization (Praja Sabha);

(2) Community participation for rural development programs in cooperation with their rural community organization;

(3) Amount of eradication of myth and misconception of the development project;

(4) Scale of awareness of the objectives and goals of the proposed development project and its implementation of development programs.

Participatory observation is conducted in following ways:

- From Project manager and Project Consultant Specialist to the development field facilitators such as Field officers, Government GN Officers, Government Agricultural Research officers can observe the difference of the rural community behavior with reference to the development programs after the novel development communication therapy of cultural show.

- Government authorities such as Divisional Secretariat, Chairman of the Divisional Council, District Development Planning officers can observe the change of the rural sector.

- In addition to this, community facilitators of the Praja Sabha and other responsible authorities of the rural society such as traditional leaders can be involved to make them understand the impact of the development communication.

In this observation, it was discovered that the majority of the rural population of development area has participated in the new communication program. At least one member of a family had participated in the communication performance. Other rural villagers were influenced by these participants' experience of development messages. Many rural members have felt a certain interest to be involved in the rural development program as a result of the new communication. In this, the new comers tried to give their optimum contribution to expand the idea of community governance to their own society from being supported only to the rural development programs. The persons who were previously deprived from the development programs at the village level had to change their attitudes and behavior as a result of being participated to the cultural.

Substantial increasing the attendance of the rural community for the Praja Sabha is another aspect of the findings of the participatory observation. It was understood that the new comers who have presented an enthusiastic contribution to the collaborative team works at the Praja Sabha. Moreover, they had shown a greater strength in participating at rural development works than the other experienced members who had worked from the very beginning. The main reason for this new change was to utilize the traditional forms of presentation skills and communication tools. It was easy to understand the traditional communication in the usage of development communication. Usage of traditional forms of communication in terms of development communication practice had been widely accepted rather than the other one way directional communication materials.

Questionnaire is distributed among the rural community to identify the impact of designed development communication. Amount of questionnaires was distributed depending on the population of rural communities who had both participated and were absent at the cultural shows.

In this social survey, questionnaire was distributed randomly among 200 respondents of the rural community. There were $57 \%$ of males, and $43 \%$ of females out of the total respondents (see Figure 2). 


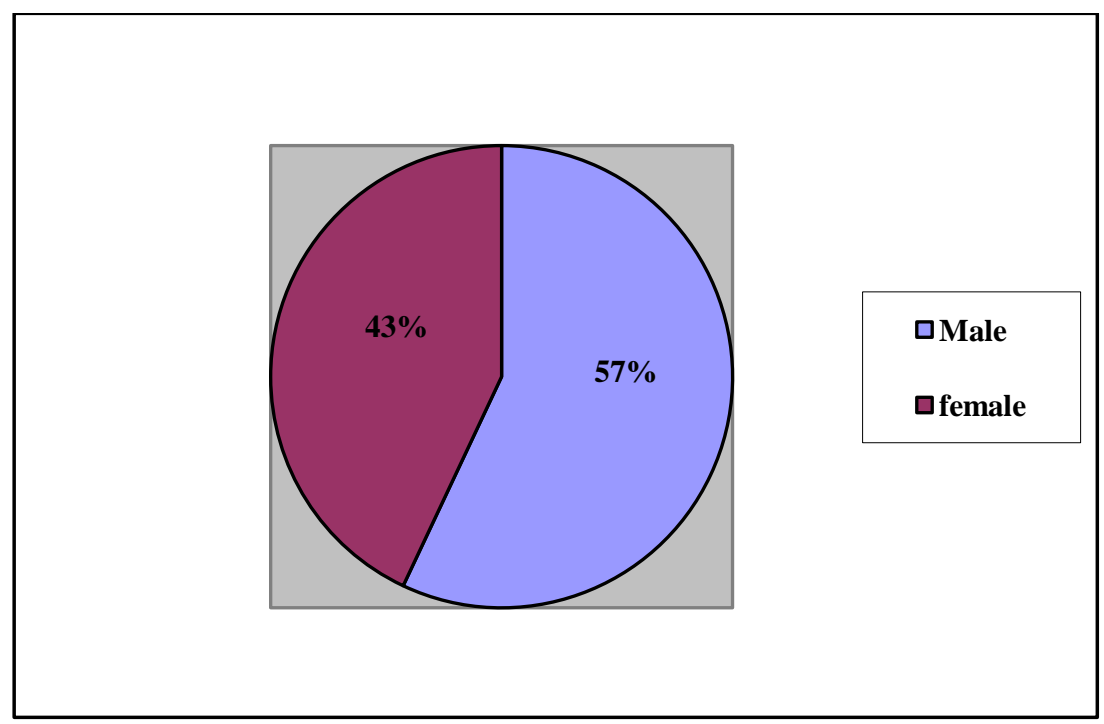

Figure 2. Gender.

Many participants were in the age of 26-45 and it was $42 \%$ out of the all. Young people have shown a greater interest to experience a such kind of cultural communication for development messages than traditional small group communication method.

(1) Age category (see Figure 3):

- Less than 10 years $10 \%$

- Between 10-15 12\%

- Between 16-25 16\%

- Between 26-35 22\%

- Between 36-45 20\%

- Between 46-55 12\%

- Over 56- $8 \%$

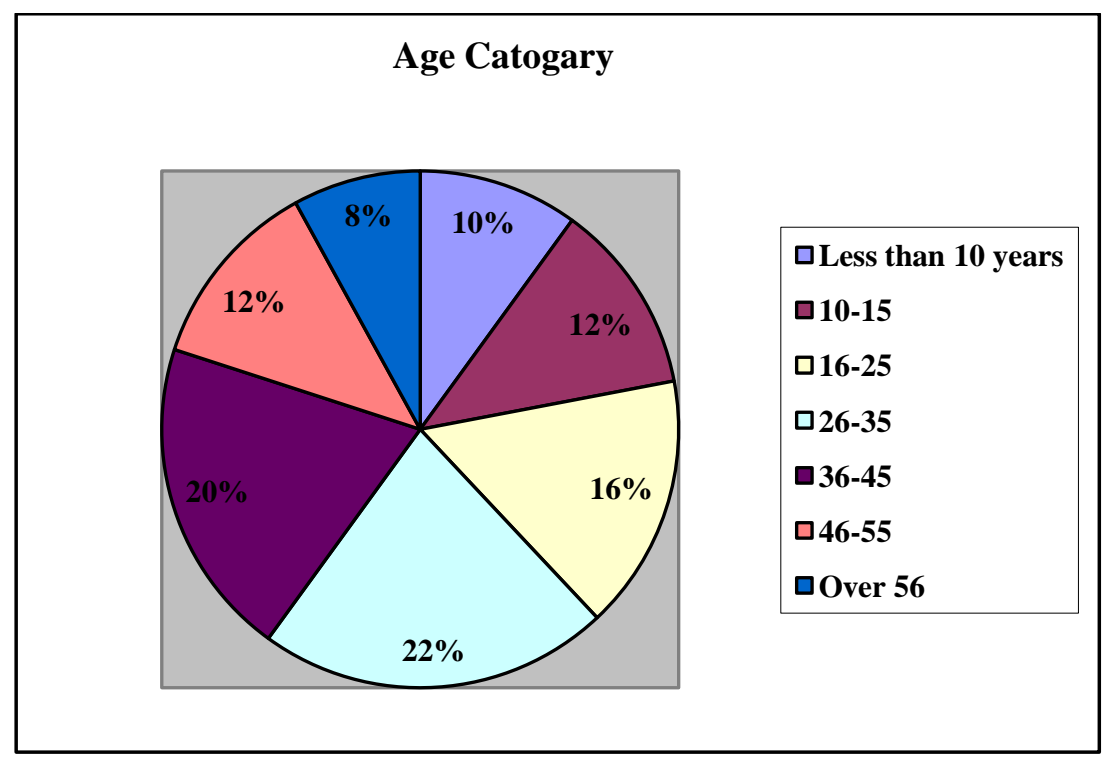

Figure 3. Age category. 
Education of the respondents could be understood from Figure 4. Majority of the rural population was below the GCE O/L (General Certificate of Education Ordinary Level) education and it was 62\%. Only $7 \%$ of the subjects who qualified university education.

(2) Education level:

- Less than $\mathrm{O} / \mathrm{L}$ education $62 \%$

- $\mathrm{A} / \mathrm{L} \quad 31 \%$

- Undergraduate $5 \%$

- Post graduate $2 \%$

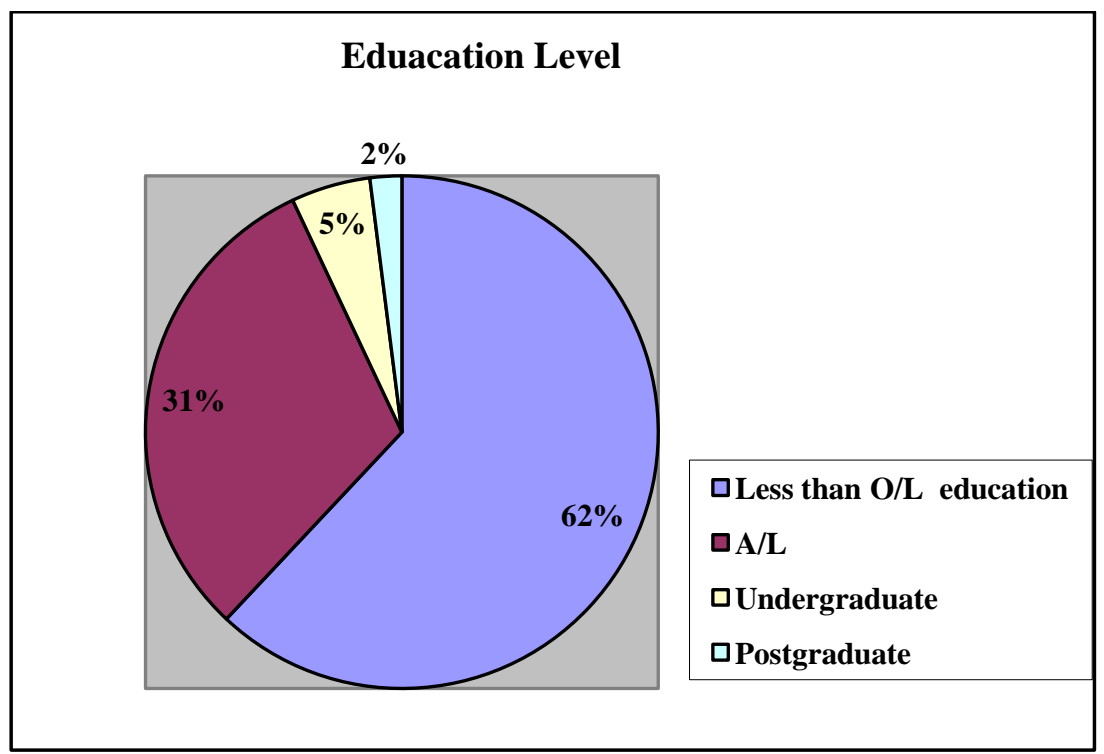

Figure 4. Education level.

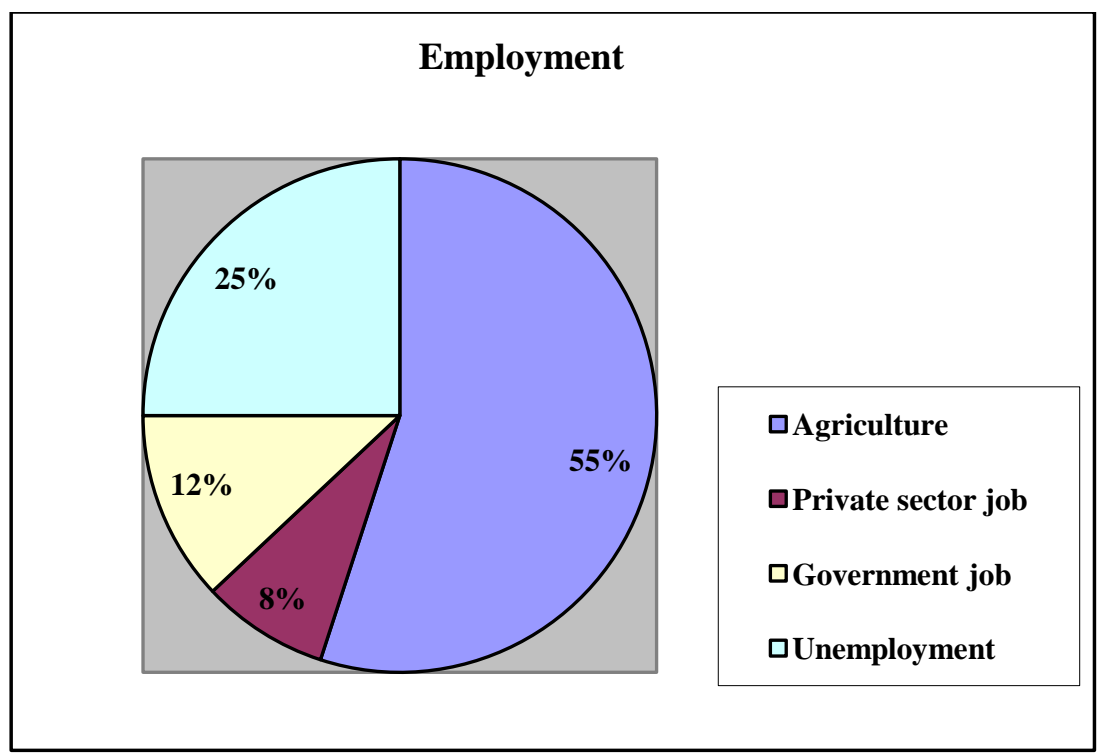

Figure 5. Employment.

From Figure 5, 55\% of the subjects were occupied in rural agricultural employments. Only $20 \%$ of the respondents had been involved in private and government jobs, while unemployed were $25 \%$. 
(3) Have you been shown the cultural show: yes / No

$68 \%$ of the subjects had experienced the cultural show of development communication, while rest of them $32 \%$ were absent.

The reason for the rejection of the experience of cultural show has been understood as different. In this, majority of the absentees agree with the lack of interests and it was $38 \%$. Only $4 \%$ of them pointed out the inefficiency of the cultural show.

(4) If No, for the above question (3), what are the reasons:

- No time

- Lack of interest

- Unavoidable circumstances

- Others

- Ineffective

\section{$23 \%$}

$38 \%$

$19 \%$

$16 \%$

$4 \%$

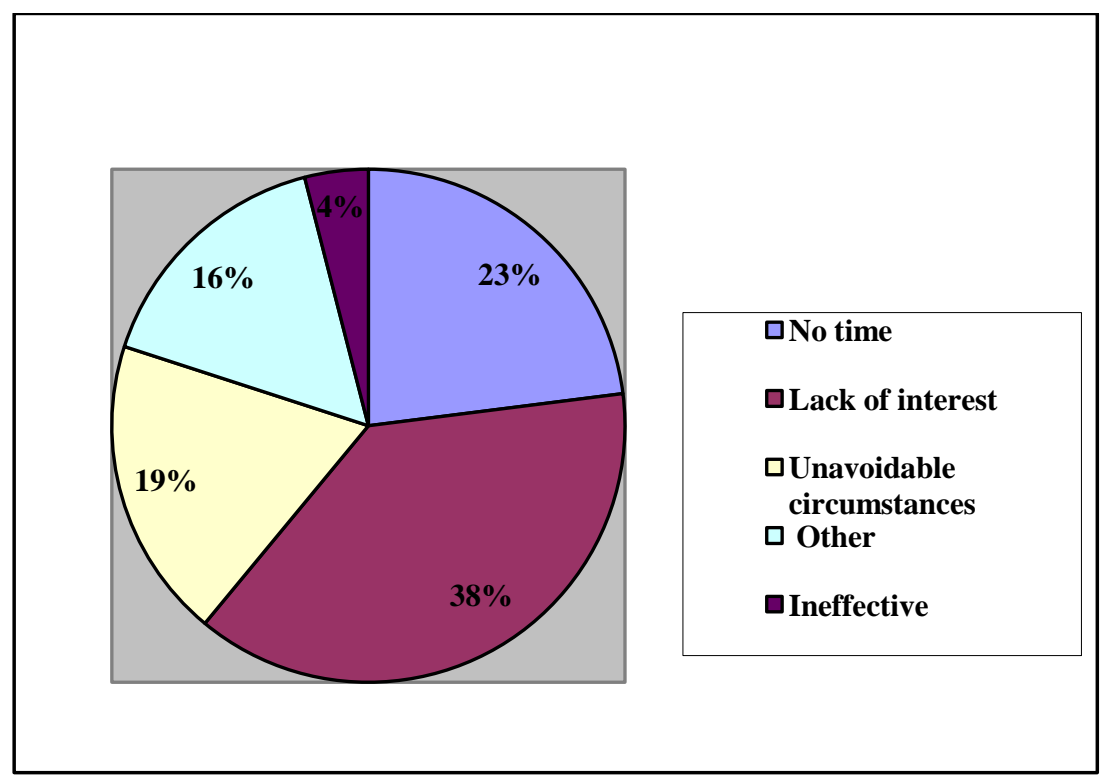

Figure 6. Communication impact.

(5) If yes for the question (3), was it more effective than the other communication patterns?: yes / no

The participants for the cultural show agree to express the high effectivity of the new communication model. It was more than the traditional communication patterns and it was $78 \%$.

(6) If yes for the question (3), how was it done (tick in serial order $1,2,3, \ldots$ )

Subjects of the research has pointed out the effectivity of the cultural show of development communication by providing some important things of the model. Theses characteristics can be mentioned below:

- Easy to Understand

- Creative

- Innovative

- Proximity

- Use of rural material and resources 
Out of them, the most highlighted reasons for taking the highest interest was serially, easy to understand, creative and use of their own rural materials and resources.

(7) What did you gain from the cultural show:

Participants of the new mode of development communication had gained the following advantages.

- Entertainment of communication

- New knowledge of development workings

- Awareness of the development project

- Motivation for the development project

Behavior of the rural community has been dramatically influenced by the new development communication model. They listed following incidents:

(8) What happened to you after the therapy of the cultural show:

- Received a proper understanding of the substance of the development Project and its objectives

- Change the behavior with attendance for the Praja sabha

- Add the fullest contribution to the rural development programs

- received a sufficient meaning of the rural community governance

- Learnt about the aspects of rural governance

Interviews were conducted using rural community who both participated and were absent for the cultural show. Interviews conducted in two ways as:

- In-depth interviews / single interviews

- Focus-group interviews.

Twenty single in-depth interviews were conducted in all the $27 \mathrm{GN}$ divisions, where the cultural show has been shown. In this session, following issues were seriously explored. Much of them were influenced by the communication. They had taken a better interest on the development project and they fully supported to the idea to participate to the Praja Sabha when they had been fully confirmed about the sincerity and the honesty of the stakeholders and the Government Officers involved in the Project. The new communication model had necessarily provided a platform to bring about a practical knowledge and awareness of the development programs and their objectives in terms of the rural community.

Ten (10) focus-group interviews were conducted, covering all the 27 GN divisions in the development area. There was an issue about conducting the cultural show in the evening due to certain reasons. Focus-group interviews were made from the members of the Praja Sabha and the persons of the organizing committee. They pointed out some negative issues regarding the organization of the cultural show. They are as follows:

- Lack of proper knowledge and understanding of the preparation of the stage and production equipments for the cultural show.

- Inability to coordinate the activities of the members of the Praja Sabha.

- At the same time they highlighted some of the positive issues of the organization.

- Ability to work and exchange the human resources.

- Enhancing the skills and competencies of the traditional cultural communication.

- A live Platform for improving team-work and cooperative skills.

- A Place for interactive stimulation for the rural community.

- A different form of communication than traditional speech oriented small group communication. 


\section{Conclusion}

Development of a country has been placed shifted by the critical analysis of post-structural theories, so that the practices of development are also in an evolving flux (Derrida, 1960). European developed nations have labeled the countries of the world into three dimensions as developed countries, under-developing countries and poor countries in terms of the achieved amount of quality and quantity of the human and natural resources and services. But how they have been empowered up to that stand is controversial. Western developed nations were built up from the natural and human resources of Asian, African and South American regions during the Colonization period. This has not been fully accepted by some of the developmental theories. This form of demarcation was severely criticized. The predominance of western economic and political ideology has created such a form of separation with the intention of highlighting western ideology. Therefore rest of the world is hesitant to admit the western development perspective at present consequences of modernization model of modern development as well. South Asian countries should try to find out their own development discourse taking into consideration on their regional, geographical, cultural and political necessities and identities. Earlier theories and applications of development communication, which were built by American and western scholars urged the relevance of mass media for the development (Shramm, 1964; Lerner, 1958; Rogers, 1962; Pye, 1964; Pool, 1983). However, they have been later largely criticized by the theories and practices of non-western communication scholars. As a result of on-going social political and economic movements and real world experiences in the developing nations in the South-American, South-African and South-Asian continents, there are number of local level development communication theories and practices (Dissanayaka, 1984; Nair \& White, 1993; Quebral, 1973; Oshima, 1982; Belbase, 1991; Juan Diaz Bordenave, 1976; Paulo Freire, 1968; Senevirathna, 2000; Jinadasa, 2011, 2014, 2015; Ascroft, 1971; Jinadasa \& Rajapaksha, 2006). Most of them have been developed by the use of their histories, cultures, regional philosophies and specially use of the traditional forms of communication albeit the mainstream use of mass media.

Under-developing countries are much familiar with the rural development programs. Rural development has taken much importance in the journey of development of a country. Rural-integrated development has been popularized recently in the context of rural development practice especially in the Asian countries like India Bangladesh, Taiwan, and Sri Lanka. In Sri Lanka, several programmes of the rural-integrated development have long been implemented like Janasaviya, Samurdhi, Gamidhiriya, Gamanaguma. But, they didn't address to the issues of the rural development which are crucial and they always highlighted the advantages of contemporary party politics. Rural-integrated development programs of Sri Lanka have not been properly understood the aspirations of the rural community in the entire process of local development, while they gratified the wants and needs of foreign donor agencies. The rural community participation for the rural development programs, from identifying rural problems to implement proposed development programs was not seriously taken by the development planners and authorities. Meanwhile, the importance of being participants for the rural development programs in their own rural community was theoretically and practically accepted justified as a global phenomenon in the development discourse.

After the independence, the discourse of Sri Lankan local development has been taken into serious consideration in many ways. It has reached nearly 60 years up to now. Government has implemented several development programs. In addition to the government role in the development sector a large number of Non-Governmental Organizations have implemented a large scale of development projects during this time 
period. But none of these could achieve the target goals of the development in the country. Government funded programs have been much concentrated on the party politics and their respective limited objectives, while non-governmental programs of development targeted on the private objectives of local and foreign funding agencies. They contribute on their narrow global and local interferences into the local industries of culture and society. Both these both phenomena have been disastrous for the development of Sri Lanka.

They were to administer the rural village from their-own governance. The term Sabha, has been rooted from the traditional rural community governance form (Roberts, 1977). Some of them were Wariga Sabha, Wel Sabha, Jala Sabha etc. Therefore traditional rural administrative systems can be logically utilized at the new forms of rural community governance programs of the development projects.

Traditional forms of communication have been used effectively for the rural development communication in mostly developing countries in Asian, African and south American regions. Use of traditional folk media with reference to the development communication have certain characteristics: such as proximity to the rural community, closeness of traditional forms of communication, rich creativity, familiar sign and symbols, rural community participation, live gatherings for effective communication, source for innovative communication, easy to adaptation, credibility to rural community.

When making communication methods for rural folks and other marginalized groups, nowadays more attention is paid to make communication tools and campaigns using traditional folk media. African and south Indian countries have paid their thorough attention on this application. They have conducted many practical studies to find out how effectively they can use the traditional folk media as a development communication method.

Traditional folk media has various types of communicative potentials. They can be utilized to build up the process of social mobilization for the community development activities. Thus, there is a trend to use the different performing qualities of folk media as an entertainment and educational media.

Traditional folk media is knowledge, wisdom, traditions, customs and life styles of the people transferred from one generation to the other by word of mouth, observation and imitation through folk groups such as family, age or region over time and space.

Traditional folk media is different from electronic and print media. When comparing traditional folk media with electronic and print media we can see that although the technology and the scope of traditional folk media is comparatively low, its ability to function as a communication tool is universal and more effective.

As these traditional folk media was being originated in rural folks themselves. They are much more effective in showing the socio-cultural needs of the people. There is a very close relationship between the rural folk and the structure and the content of the traditional folk media. This proximity contributes in many ways in conveying the message faster and more effectively.

The symbols and codes used in traditional folk media are not hostile to that community. When we get used to the symbols and codes of a particular media, we can understand that media and the messages conveyed using that media very quickly. Also it's important to note that as traditional mass consciousness is a part of these signs, symbols \& codes. It has been successfully transferred from one generation to another.

To use traditional folk media, people do not have to be as literate as they should be to use mass media, especially electronic and printed media. Traditional folk media can be easily comprehended as they use their-own simple diction and language, as they show a lot of respect and devotion in religious activities as they always respect and obey the adults and listen to their advices and as they are very flexible. 
The closeness between traditional folk media and the community. People often complain that the electronic and printed media talk more about the viewpoints and the needs of the urban folks than those of the rural folks. On the other hand, rural media helps a lot when they have to find solutions to their day to day problems. For example diseases like measles, mumps, chiken pops, etc are called God's diseases (Deiyange Leda). People relieve themselves by asking god to cure these diseases as they are very critical. They express it symbolically by hanging a small Khomba (Margosa/wormwood-Azadirachta Indika)twig in front of the house. They believe in white magic without ever questioning the consequences of it. This immaculate belief is capable of curing the disease.

Traditional folk media is active in participation, co-operation $\&$ interactive communication. Folk media thus becomes more a group work than a individual task. Even the presentation is done by a group of people. Therefore traditional folk media helps to re-establish qualities like co-operation, ability to work together as a group \& community participation that is essential for rural folk development. Participation of a group of people can be seen in occasions such as Aththama (planting paddies in collaborative behavior in each of their fields respectively), Kaiya, Pinkama (Buddhist religious practice conduct in group behavior), \& funerals and so on. In the Bali ritual, the patient is cured because of the novel socialization after a long illness in an isolated cabin in their house. There, the patient gets a lot of confidence and is psychologically cured as he gets a lot of attention and finally becomes the center of attraction.

Traditional mass media is live, creative and can be changed easily with innovation. In brief, it is deconstructive at any challenging event. Unlike mass media, folk media is a part and parcel of the folk life. An interpersonal communication is done through gestures and postures. There is direct feed back and reaction between the presenters and the spectators. Therefore the message can be altered and creatively modified. Like this there are so many positive qualities of traditional folk media.

Sri Lankan traditional folk media has often been studied only on the light of dance, theatre and drama. There are minimal studies that have been done to find out as to how to make use of their sociological and communicative abilities in development communication.

Using the popular traditional folk media that can be seen at present, we can study its content and structure in depth and can explore how to use them in local development communication.

In spite of the minimal disadvantages, this proposed communication model may be utilized in the rural community development programs with its more capacities to convince the target communities of the rural development program. Reciprocal relationship, mutual understanding, credibility, practical awareness are some of the fruits that can gain in turn as a result of using folk media for the local development communication leading to community empowerment participatory development projects.

\section{References}

Ariyaratne, A. T. (1986). Asian values as a basis for Asian development. In D. C. Korten (Ed.), Community management: Asian experience and perspectives (pp. 32-39). West Hartford, CT: Kumarian Press.

Ariyaratne, A. T. (1987). Beyond development communication: Case study on Sarvodaya, Sri Lanka. In N. Jayaweera, \& S. Amunugama (Eds.), Rethinking development communication (pp. 239-251). Singapore: Asian Mass Communication Research and Information Center.

Bond, G. D. (2004). Buddhism at work: Community development, social empowerment and the Sarvodaya movement. Bloomfield, CT: Kumarian Press.

Chitty, N. (2004). Configuring the future. Journal of International Communication, 10(2), 42-66.

Chitty, N. (2010). Mapping Asian international communication. Asian Journal of Communication, 20(2), 181-196. 
Danapala, J. (2002). Communicating the disarmament message. Journal of International Communication, 8(1), 9-18.

Dissanayaka, W. (1979). Sanwardana Sanniwedanaya (Development Communication). Colombo, Sri Lanka: Indika Printers.

Dissanayake, W. (1983a). Communication in the cultural traditions of India. Media Development, 30(1), 27-30.

Dissanayake, W. (1983b). The communication significance of the Buddhist concept of dependent co-origination. Communication, $8(1), 29-45$

Dissanayake, W. (1986). The need for the study of Asian approaches to communication. Media Asia, 13(1), 6-13.

Dissanayake, W. (1988). Communication theory: The Asian perspective. Singapore: AMIC.

Dissanayake, W. (2009). The desire to excavate Asian theories of communication: One strand of the history. Journal of Multicultural Discourses, 4(1), 7-27.

Dissanayake, W. (2009). The production of Asian theories of communication: Contexts and challenges. Asian Journal of Communication, 19(4), 453-468.

Dissanayake, W. (2014). Development and communication in Sri Lanka: A Buddhist approach. In M. K. Asante, Y. Miike, \& J. Yin (Eds.), The global intercultural communication reader (pp. 467-479). New York, NY: Routledge.

Goonasekera, A. (1985). Toward the development of mass media for the third World. The Third Channel, 1(2), 224-236.

Goonasekera, A. (1990). Mass media campaigns for development: Some practical guidelines. The Journal of Development Communication, 1(1), 47-54.

Goonasekera, A. (1995). Communication studies and contemporary societies in Asia. Media Development, 42(2), 21-24.

Gunaratne, S. A. (1991). Asian approaches to communication theory. Media Development, 38(1), 53-55.

Gunaratne, S. A. (2007). A Buddhist view of journalism: Emphasis on mutual interdependence. Communication for Development and Social Change, 1(3), 17-38.

Gunaratne, S. A. (2009). Asian communication theory. In S. W. Littlejohn, \& K. A. Foss (Eds.), Encyclopedia of communication theory (pp. 47-52). Thousand Oaks, CA: Sage.

Gunaratne, S. A. (2009). Globalization: A non-western perspective: The bias of social science/communication Oligopoly. Communication, Culture \& Critique, 2, 60-82.

Hartwick, E. (2005). Theories of development. Jaipur: Rawat.

Ishii, S. (2009). Conceptualizing Asian communication ethics: A Buddhist perspective. Journal of Multicultural Discourses, 4(1), 49-60.

Jajapaksha, C. (1998). Kudakandayam Sanniwedanaya (Small group communication). Colombo, Sri Lanka: Rathna Publications. Jayaweera, N. (1993). Folk-media and development communication: Myth and realities. Nugegoda: Author.

Jinadasa, M. P. K. (2009). Bali Abum Kavi Potha-2 (Book of the Traditional lyrics that explain the methods of creating Bali Figures-02). Colombo: Godage \& Brothers Publishers.

Jinadasa, M. P. K. (2010). Bali Abum Kavi Potha-1 (Book of the Traditional lyrics that explain the methods of creating Bali Figures-01).Colombo: Godage \& Brothers Publishers.

Jinadasa, M. P. K. (2010). Bali Sannededanaya (Bali ritual and Communicational Meanings). Colombo: Godage \& Brothers Publishers.

Jinadasa, M. P. K. (2011b). Sanwardanaya, Paryeshanaya Saha Mahajana Sambandathawaya (Development, research and public relations). Kadawatha: Jayavi Printers.

Jinadasa, M. P. K. (2011c). Development communication: Theory and practice. Colombo: Godage International Publishers.

Jinadasa, M. P. K. (2013). Jathyantara Sanniwedanaya (International Communication). Colombo: Godage \& Brothers Publishers.

Jinadasa, M. P. K. (2014). Sanwardana Sanniwedanaya (Development communication). ICCR, Madamahanuwara.

Jinadasa, W. W. M. P. K. (2015). Community development programmes and folk-media: A communication model for Sri Lankan rural society. Retrieved from http://www.caluniv.ac.in/global-mdia-journal/Winter\%20Issue\%20December\%20\%202011\%20Articles/AR-4\%20Jinadasa.p df

Lerner, D. (1958). The passing of traditional society: Modernizing the Middle East. Illinois: The Free Press.

Lerner, D., \& Nelson, L. M. (1977). Communication research a half-century Appraisal. Honalulu: East-West Center University Press of Hawai.

Lerner, D., \& Schramm, W. (1967). Communication and change in the developing countries. Honolulu: East West Center.

Lokuliyana, A. (2001). Santhikarma Sanniwedanaya (Ritualistic Communication in Sri Lanka). Maradana: Sri Lanka Godage.

Macy, J. (1985). Dharma and development: Religion as resource in the Sarvodaya self-help movement (Rev. ed.). West Hartford, CT: Kumarian Press. 
Mahendra, S. (1992). Man and myth. Maradana, Kohuwala, Sri Lanka: Udaya Publication.

Mahendra, S. (1995). Janashruthiya Ha Nirmanaya (Folk-Lore and Creation). Maradana, Sri Lanka: Godage.

Melkote, S. R., \& Steeves, H. L. (2001). Communication for development in the third world: Theory and practice for Empowerment. New Delhi: Sage.

Melkote, S. R., \& Steeves, H. L. (2001). Communication for development in the third world: Theory and Practice. New Delhi: Sage.

Mody, B. (1991). Designing messages for development communication: An audience participation based approach. New Delhi: Sage.

Mody, B. (2003). International and development communication: A 21st century perspective. London: Sage.

Mowlana, H. (2003). Communication, philosophy and religion. Journal of International Communication, 9(1), 11-34.

Pieterse, J. N. (2001). Development theory: Deconstructions/Reconstructions. New Delhi: Vistaar.

Piyadasa, R. L. P. (2014). Purana Gama (Ancient Village in Sri Lanka). Kandy: Centre for Development and Media.

Roberts, M. (1977). Documents of the Ceylon national congress and national politics in Ceylon 1929-1950. Colombo: Department of National Archives.

Rodloytuk, P. (2007). Buddhist participatory communication for rural development. Journal of International Communication, 13(1), 119-136.

Rogers, E. M. (1962). Diffusion of innovations. New York: The Free Press.

Schramm, W. (1964). Mass media and national development: The role of information in the developing countries. Stanford: Stanford University Press.

Schramm, W., \& Lerner, D. (1978). Communication and change: The last ten years-and next. Honolulu: East West Center.

Schramm, W., \& Roberts, D. F. (1974). The process and effect of mass communication. London: University of Illinois Press.

White, S. A. (1999). The art of facilitating participation: Releasing the power of Grassroots communication. New Delhi: Sage.

White, S. A. (2002). Participatory communication: Working for change and development.New Delhi: Sage.

\section{Appendix}

\section{A. 27 Grama Niladari Divisions( GN Divisions)}

1. Abale

2. Udunowa

3. Agarauda

4. Thalakolawawa

5. Abagammana

6. Koongaswalayagama

7. Diullawa

8. Unagolla

9. Rabewa

10. Leekolapitiya

11. Malpanawa

12. Kooralayagama

13. Halabe

14. Ottukolama

15. Galpanama

16. Aabokkagama

17. Kanuketiya

18. Rasnayakapura

19. Nammuwawa 
20. Kanagullewa

21. Niraliyadda

22. Kallanchiya

23. Kadigawayaya-03

24. Kadigawayaya-01

25. Kuruwikulama

26. Subasinhapura

27. Magurankadawala

\section{B. Identified development issues}

1. Lack of incoming

2. Lack of drinking water

3. Lack of relevant facilities for agriculture

4. Insufficiency of service facilities

5. Difficulties of transportation

6. Decreasing Social ethics

7. Educational problems

8. Absence of flowing new knowledge and information to rural society

9. Lack of electricity in certain areas

10. Absence of cooperation

11. Road Difficulties

12. Health and sanitation problems

13. Threat from wild elephants

14. Lack of organizational skills / avoidance of responsibilities

15. Absence of a programme for women's development

16. Absence of a progrmamme for developing marginalized and disable people

17. Drugs and Arrack hazard

18. Absence of a programme for youth development

19. Problems of land ownership

20. Insufficiency of public facilities

21. Family problems

22. Environmental problems

23. Problems of public resources and management

24. Problems of child development

25. Absence of permanent houses

26. Unreachable of the services due to the ignorance of the community

27. Private utilization of the public resources

28. Absence of a proper planning for both private and public services

29. Absence of a programme to advance the innate skills of the individuals

30. Insecurity of local medicine and their resources 